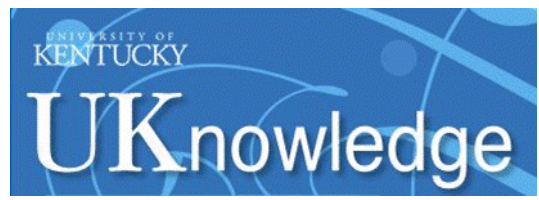

University of Kentucky

UKnowledge

\title{
Using Neonatal Skin to Study the Developmental Programming of Aging
}

\author{
Leryn J. Reynolds \\ University of Kentucky, leryn.reynolds@uky.edu \\ Brett J. Dickens \\ University of Kentucky, brett.dickens@uky.edu \\ Benjamin B. Green \\ Dartmouth College \\ Carmen J. Marsit \\ Emory University \\ Kevin J. Pearson \\ University of Kentucky, kevin.pearson@uky.edu
}

Follow this and additional works at: https://uknowledge.uky.edu/pharmacol_facpub

Part of the Diseases Commons, Gerontology Commons, and the Pharmacology, Toxicology and

Environmental Health Commons

Right click to open a feedback form in a new tab to let us know how this document benefits you.

\section{Repository Citation}

Reynolds, Leryn J.; Dickens, Brett J.; Green, Benjamin B.; Marsit, Carmen J.; and Pearson, Kevin J., "Using Neonatal Skin to Study the Developmental Programming of Aging" (2017). Pharmacology and Nutritional Sciences Faculty Publications. 84.

https://uknowledge.uky.edu/pharmacol_facpub/84

This Article is brought to you for free and open access by the Pharmacology and Nutritional Sciences at UKnowledge. It has been accepted for inclusion in Pharmacology and Nutritional Sciences Faculty Publications by an authorized administrator of UKnowledge. For more information, please contact UKnowledge@lsv.uky.edu. 
Using Neonatal Skin to Study the Developmental Programming of Aging

Digital Object Identifier (DOI)

https://doi.org/10.1016/j.exger.2016.12.015

Notes/Citation Information

Published in Experimental Gerontology, v. 94, p. 93-98.

(C) 2016 Elsevier Inc. All rights reserved.

This manuscript version is made available under the CC-BY-NC-ND 4.0 license

https://creativecommons.org/licenses/by-nc-nd/4.0/.

The document available for download is the author's post-peer-review final draft of the article.

This article is available at UKnowledge: https://uknowledge.uky.edu/pharmacol_facpub/84 


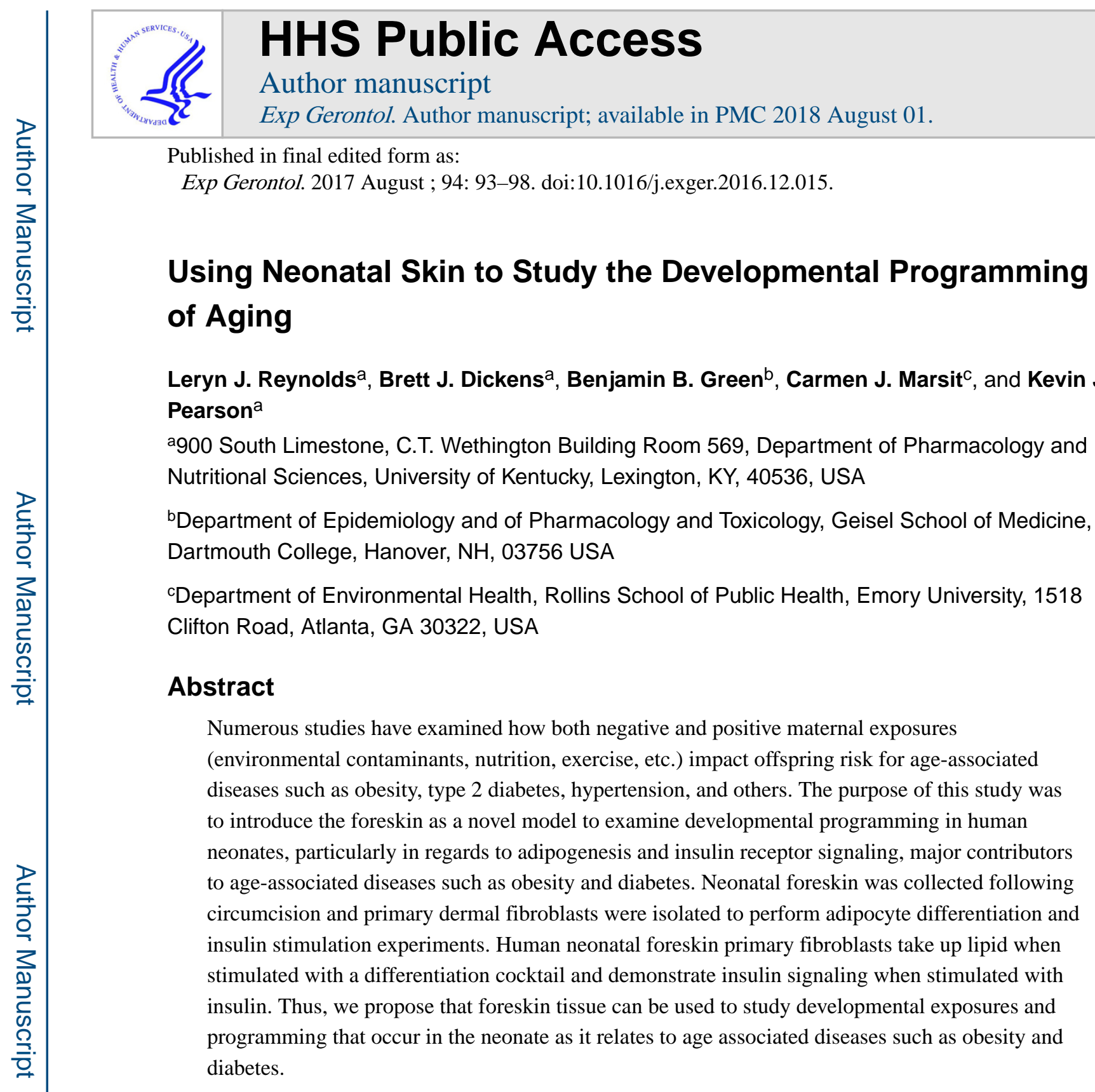

\section{Keywords}

epigenetics; insulin sensitivity; obesity; pregnancy; adipogenesis; DOHaD

Corresponding Author: Kevin J. Pearson, 900 S. Limestone, University of Kentucky, C.T. Wethington Bldg 571, Lexington, KY 40536, Kevin.pearson@uky.edu, 859-218-1371.

Publisher's Disclaimer: This is a PDF file of an unedited manuscript that has been accepted for publication. As a service to our customers we are providing this early version of the manuscript. The manuscript will undergo copyediting, typesetting, and review of the resulting proof before it is published in its final citable form. Please note that during the production process errors may be discovered which could affect the content, and all legal disclaimers that apply to the journal pertain.

CONFLICTS OF INTEREST:

The authors have no conflicts of interest to report. 


\subsection{INTRODUCTION}

The Barker hypothesis supports that maternal under-nutrition during pregnancy reprograms offspring to be at greater risk for developing cardiovascular and metabolic disease later in life (Barker et al., 1993). Since this early work, the Developmental Origins of Health and Disease $(\mathrm{DOHaD})$ hypothesis has been expanded to include a large number of intrauterine exposures during fetal and early postnatal development (Wadhwa et al., 2009). Numerous studies have examined how negative and even positive maternal exposures (environmental contaminants, nutrition, exercise, etc.) impact fetal development and long-term offspring health. Studies report altered risk of obesity, type 2 diabetes, hypertension, and others in offspring from mothers who are exposed to a number of environmental influences (Alfaradhi et al., 2014; Carter et al., 2012; Carter et al., 2013; Ino, 2010; Rashid et al., 2013; Swanson et al., 2009; Wang et al., 2002; Zhang et al., 2014). Further, obesity and type 2 diabetes are associated with early death (Kitahara et al., 2014; Leal et al., 2009). Thus, understanding how to prevent and treat obesity and type 2 diabetes is crucial to healthy aging.

The Dutch Famine of 1944 presented a unique time to study developmental programming and specifically the impact of undernutrition during pregnancy on offspring late life disease risk. Roseboom et al. found that adult children born to mothers undernourished during pregnancy were smaller at birth and had increased prevalence of cardiovascular disease morbidity and mortality compared to adult children who were not exposed to undernutrition in utero (Roseboom et al., 2001). Heijmans et al., (Heijmans et al., 2008) followed up on these studies and demonstrated that whole blood samples from adults who were exposed to the famine 6 decades earlier had reduced insulin-like growth factor-2 (IGF2) differentially methylated region (DMR) compared to their same sex siblings not exposed to famine. This study was one of the first to provide empirical evidence that undernutrition during gestation epigenetically alters individuals. Since these landmark studies, over 126 articles have been published using the key phrases "developmental programing aging" on PubMed, expanding upon the idea that maternal environmental exposures can impact long-term healthy aging.

Gavrilov and Gavrilova put forth the High Initial Damage Load Hypothesis which suggests that high amounts of damage early in development contribute to the accumulated damage associated with aging later in life, giving these events a large impact on lifespan (Gavrilov and Gavrilova, 2004). The basis of their hypothesis stems from studies suggesting that human paternal age can influence aging rates in female offspring (Gavrilov et al., 1997), and the season of birth can affect human longevity (Gavrilov and Gavrilova, 1999). Using animal models, Ozanne and Hales found that offspring born to female mice fed a protein restricted diet had decreased longevity when fed a normal or high fat diet after birth (Ozanne and Hales, 2004; Ozanne and Hales, 2005). These mice were born lighter than offspring from standard diet fed females, but they achieved rapid "catch-up" growth early in life and aged more rapidly. Miller et al. have been studying the importance of growth trajectories and found that smaller mice, at young and old age, generally live longer in the absence of the catch-up growth seen in the studies by Ozanne (Miller et al., 2000; Miller et al., 2002). In addition, Sun et al. found that increasing litter size from 8 to 12 pups during nursing increased lifespan of the offspring due to decreased growth (Sun et al., 2009). Together these data suggest that age-related mechanisms and lifespan can be influenced by the prenatal or 
early postnatal environment. Given that pregnancy in humans is only $\sim 40$ weeks and the entire lifespan of a human living in the United States of America is on average 78.8 years (CDC, 2015), the relative investment in time during pregnancy is low to make positive modifiable behavior changes which can impact offspring health for years to follow. However, examining the mechanisms of how maternal behaviors/exposures during pregnancy directly impact offspring health in humans is a major challenge.

Globally, many laboratories are investigating molecular and physiologic features in accessible newborn tissues, such as human placenta and cord blood to explore developmental changes induced by maternal parameters, and these samples have provided valuable information about in utero exposures. However, these provide a cross-sectional snapshot of potential variation accumulated over the course of pregnancy, and generally, do not allow for experimental manipulation to determine the functional relevance of these characteristics. In order to overcome these challenges, we propose to use the foreskin as a model to study developmental programming in humans. The skin is readily available via circumcision at birth and through skin punches later allowing for lifelong aging comparisons. This reason sets it apart from the placenta and cord blood, which represent unique samples available at birth. The foreskin is generally considered a waste tissue and thus is readily available where circumcisions are performed. Further, there is ample tissue (roughly $400 \mathrm{mg}$ per foreskin) present for the extraction of RNA, DNA, or protein. In addition, primary fibroblasts can be isolated from the dermal layer and will allow for the creation of an in vitro system for living cell experiments that are representative of the neonatal environment (or in utero exposures). In fact, other laboratories are already utilizing skin-derived fibroblasts in the study of aging (Harper et al., 2007; Salmon et al., 2005). The purpose of this study is to introduce the foreskin as a novel model to examine developmental programming in human neonates, particularly in regards to adipogenesis and insulin receptor signaling, major contributors to age-associated disease.

\subsection{METHODS}

Approximately 58\% of male infants in the United States are circumcised (Owings, 2013). Neonatal foreskins from the Birthing Center at the University of Kentucky Chandler Hospital were collected immediately following planned circumcision into phosphate buffered saline (PBS) and transported on ice to the laboratory. Foreskins were collected from male infants undergoing routine circumcision within 96 hours of birth. Study protocols were either approved by or considered exempt by the Institutional Review Board of the University of Kentucky.

\subsection{Experimental Design}

\subsubsection{Experiment 1: Confirm that foreskin primary dermal fibroblasts differentiate into lipid droplets and markers regulating adipogenesis appear to be regulated epigenetically-Markers of increased and decreased adiposity such as} fatty acid binding protein 4 (FABP4) (mRNA) (Krusinova and Pelikanova, 2008; Terra et al., 2011) and Ras and Rab Interactor 3 (RIN3) (mRNA and DNA methylation), respectively, 
(Padilla et al., 2014; Wens et al., 2013) were measured from foreskin primary dermal fibroblasts.

2.1.2 Dissection and plating of foreskin dermal primary fibroblasts-Fat and loose fascia (dartos/hypodermal layer) were grossly dissected away from the epidermal/ dermal layers. Dermal cells were isolated and plated according to standardized procedures from Life Technologies with slight modifications. In brief, tissue was treated with $5 \mathrm{~mL}$ dispase II solution (25 U/mL) (Life Technologies, catalogue \#17105-041) for 16-20 hours in order to separate the dermis from the epidermis. Using forceps, the epidermis was peeled from the dermis and discarded. The dermal layer was put in a culture dish with $10 \mathrm{~mL}$ of media (Gibco, catalogue \#10569-010) supplemented with 10\% fetal bovine serum and gentamicin/amphotericin (Life Technologies, catalogue \#R01510) and cut into small pieces. Media and dermal pieces were then placed in a $50 \mathrm{~mL}$ conical tube with $10 \mathrm{~mL}$ of collagenase type IV solution (1,500 U/mL) (Life Technologies, catalogue \#17104-019) with an additional $10 \mathrm{~mL}$ of media (total of $30 \mathrm{~mL}$ ) for 1 hour at $37^{\circ} \mathrm{C}$. Every 15 min the tube was shaken for 30 seconds to agitate and breakdown dermal pieces. Following digestion, the conical tube was spun at $180 \mathrm{~g}$ for $7 \mathrm{~min}$ to pellet tissue and cells. Media and collagenase were aspirated off and cells were re-suspended in $5 \mathrm{~mL}$ of media. The media was then filtered through a $0.22 \mu \mathrm{m}$ filter (BD Transduction, catalogue \#352340) onto a $100 \times 20 \mathrm{~mm}$ round plate. Another $5 \mathrm{~mL}$ of media was rinsed through the filter and added onto the plate. Cells were grown in a $37^{\circ} \mathrm{C}$ incubator with $5 \% \mathrm{CO}_{2}$. Media was changed 24 hours following plating and every 48 hours following until cells were at $80 \%$ confluency (generally 3-4 days). Cells were passaged onto a 12 well plate for adipocyte differentiation experiments.

2.1.3 Adipocyte Differentiation-Two days following confluency, adipocyte differentiation induction medium [cocktail of media (Gibco, catalogue \#10569-010), 10\% fetal bovine serum, gentamicin/amphotericin, $1 \mu \mathrm{M}$ dexamethasone, $0.5 \mathrm{mM} 3$-isobutyl-1methylxanthine, $10 \mu \mathrm{g} / \mathrm{mL}$ insulin and $1.0 \mu \mathrm{M}$ rosiglitazone] was added to half of the wells for 72 hours to induce adipocyte differentiation. The remaining wells served as controls and only contained cell media (Gibco, catalogue \#10569-010), 10\% fetal bovine serum and amphotericin. Insulin $(10 \mu \mathrm{g} / \mathrm{mL})$, rosiglitazone $(1.0 \mu \mathrm{M})$, and cell media were replaced every 48 hours for an additional 11 days. Media was refreshed on the control cells at the same time. Cells were stained for lipid droplets (described below) and DNA, RNA, and protein were collected.

2.1.4 DNA methylation-Foreskins were collected and dermal primary fibroblasts grown in culture on 12-well plates. Cells were isolated for the examination of DNA methylation of an array of genes assessed 48 hours post-confluency and 14 days following adipogenesis (Section 2.1.3) (Green et al., 2016). DNA was extracted from cell pellets using the Qiagen DNease mini kit via standard manufacturer procedures, and the quality and quantity of DNA was assessed via NanoDrop spectrophotometry. Isolated DNA underwent sodium bisulfite modification using the EZ Methylation kit (Zymo Research, Irvine, CA), were plated randomly across 12 sample batches, and assessed for genome-wide DNA methylation using the Infinium MethylationEPIC Bead Chip (Illumina, San Diego, CA) profiling methylation status for approximately $800,000 \mathrm{CpG}$ loci. The microarrays were processed at the 
Biomedical Genomics Center at the University of Minnesota (Minneapolis, MN) following manufacturer's protocol. Data was assembled using the BeadStudio methylation software package (Illumina) and then processed using the 'minfi' package in R (R Core Team 2013). Data were normalized using the functional normalization (funNorm) protocol within the 'minfi' package as specified by the software authors (Guide available at: http:// bioconductor.org/packages/release/bioc/html/minfi.html). Following normalization, all X and Y probes were removed. Differentially methylated loci were identified with a $2 \times 2$ factorial linear regression where individual subjects were included as a random effect. Within the linear model, contrasts were made between cultures before and after adipogenic differentiation. Bonferroni correction was used when appropriate.

2.1.5 RNA quantification-RNA was collected and isolated from a different set of primary dermal fibroblasts than those included in the DNA methylation experiments using standard procedures from the Qiagen RNeasy kit. mRNA of RIN3 and FABP4 were assessed via quantitative real-time PCR using the Step One Plus Real-Time PCR System (Applied Biosystems, Life Technologies). 20 ng cDNA per reaction was used with RIN3 or FABP4 TaqMan Probes (Applied Biosystems, Life Technologies). Tubulin, beta class I (TUBB) was selected as the housekeeping gene.

2.1.6 Protein quantification-Protein was collected from primary fibroblasts following 14 days of incubation in the adipogenic cocktail as described above. Briefly, $50 \mu \mathrm{L}$ of RIPA buffer (ThermoFisher Scientific, catalogue \# 89900) was added to each well for $5 \mathrm{~min}$. Cells were collected after scraping with a cell scraper and immediately frozen at $-80^{\circ} \mathrm{C}$ until analysis for FABP4 protein via ELISA (R\&D Systems, catalogue \# DFBP40). A Bradford protein assay was used to assess protein concentration of each sample.

2.1.7 Oil Red O staining-Oil Red O staining was performed with modifications as previously described (Zhang et al., 2013). $0.25 \mathrm{~g}$ of Oil Red O (Sigma, catalogue \#O-0625) was mixed with $50 \mathrm{~mL}$ of isopropanol. $15 \mathrm{~mL}$ of this stock Oil Red O solution was mixed with $10 \mathrm{~mL}$ of $\mathrm{diH}_{2} \mathrm{O}$ and sat at room temperature for at least $5 \mathrm{~min}$ prior to filtration (Millipore, catalogue \#8CGP00525) to make the working solution of Oil Red O. Cells were placed in 4\% paraformaldehyde (Sigma, catalogue \#441244) for 15 min prior to being washed once for $5 \mathrm{~min}$ in phosphate buffer saline (PBS). The cells were incubated in PBS for $5 \mathrm{~min}$ and then $60 \%$ isopropanol for an additional $5 \mathrm{~min}$. Isopropanol was removed and Oil Red O working solution was added to each well for $30 \mathrm{~min}$. Following removal of Oil Red $\mathrm{O}$, cells were washed 4 times for $5 \mathrm{~min}$ in $\mathrm{diH}_{2} \mathrm{O}$ and imaged. After imaging, cells were treated with $100 \%$ isopropanol and Oil Red O was extracted out of each well. The isopropanol/Oil Red O solution $(250 \mathrm{uL})$ was loaded in triplicate on a 96 well plate and read on a plate reader at $500 \mathrm{~nm}$ for quantification of Oil Red O staining in each well.

\subsubsection{Experiment 2: Examine whether primary dermal fibroblasts respond to} insulin stimulation-Foreskins were collected and plated as described in section 2.1.2 to assess insulin signaling proteins following insulin stimulation. Cells were stimulated with insulin for $15 \mathrm{~min}$ and protein collected to assess phosphorylation of Protein Kinase B (pAKT) and AKT signaling.

Exp Gerontol. Author manuscript; available in PMC 2018 August 01. 
2.2.2 Insulin Signaling-Primary fibroblasts from each of the 10 samples were plated onto 2, $60 \mathrm{~mm} \times 15 \mathrm{~mm}$ style cell culture dishes. 24 hours post confluency media was removed from cells and Krebs-Ringer-Phosphate (KRP) buffer plus 1\% BSA was added and the cells incubated for $1 \mathrm{hr}$ at $37^{\circ} \mathrm{C}$. Then half of the plates were treated with $100 \mathrm{nM}$ insulin (Sigma, catalogue \#I0908) for $30 \mathrm{~min}$ and half served as controls with KRP buffer only. Cells were washed twice in cold KRP buffer and protein collected as described above. Protein from each sample was mixed with cell lysis buffer and $5 \times$ Laemmli to dilute each sample to $2 \mathrm{ug} / \mathrm{uL}$. 20 ug of sample was loaded onto a 10\% gel (Bio-Rad, California, USA) and run at 100 volts for $10 \mathrm{~min}$, then 200 volts for $45 \mathrm{~min}$. Protein in the gel was then transferred to membrane at 100 volts for $45 \mathrm{~min}$ and incubated for 1 hour at room temperature in 5\% milk. Total AKT (Cell Signaling, catalogue \#4685s) and pAKT ser 473 (Cell Signaling, catalogue \#9271S) primary antibodies were added to each respective membrane overnight at 1:1000 dilution at $4^{\circ} \mathrm{C}$. Membranes were washed 3 times for $5 \mathrm{~min}$ in Tris-Buffered Saline and Tween 20 buffer (TBST) and secondary antibody (Life Technologies, catalogue \#A10547) was added at 1:2000 dilution for 1 hour at room temperature. Membranes were washed again ( 5 times for 5 min each in TBST) and imaged using femto max (Life Technologies, catalogue \#34095). Bands were quantified using Quantity One software (Bio-Rad).

2.3.1 Statistics-A one tailed, paired, student's t-test was used to analyze the difference in pAKT and AKT in non-stimulated and insulin stimulated cells and change in adipogenesis (mRNA, protein, and Oil Red O staining) in basal and differentiated cells. Natural log transformation was performed where data were not normally distributed (FABP4 mRNA and protein). Significance was set at $p<0.05$ and individual data points are shown on figures with median bars.

\subsection{RESULTS}

\subsection{Primary Dermal Fibroblasts}

\subsubsection{Experiment 1: Confirm that foreskin primary dermal fibroblasts} differentiate into lipid droplets and markers regulating adipogenesis appear to be regulated epigenetically-Primary neonatal fibroblasts incubated in the adipogenesis media for 14 days showed a significantly greater abundance of vacuoles staining positive with Oil Red O (Fig. 1A) compared to basal conditions ( $\mathrm{p}=0.002$ ). FABP4 mRNA (Figure 1B) and protein (Figure 1C) were significantly increased in the differentiated cells compared to basal conditions $(\mathrm{p}<0.001)$.

Genome-wide DNA methylation analysis indicated that $459 \mathrm{CpG}$ sites demonstrated differential methylation between differentiated and basal cells (Bonferroni, $\mathrm{p}<0.05$ ), with probe ch.14.1488981R, in the promoter region of the RIN3 gene exhibiting the greatest differential methylation of an identified gene following adipogenesis. The DNA methylation was significantly higher at this site in cells following adipogenesis (Figure 2A) compared to the basal state $(\mathrm{p}<0.001)$.

To then assess the functional importance of this methylation change, we examined expression of the gene via qPCR, and demonstrated a significantly reduced expression of 
RIN3 mRNA following adipogenesis compared to basal ( $p<0.05$, Figure 2B), suggesting that methylation may be functionally reducing the gene expression.

\subsubsection{Experiment 2: Examine whether primary dermal fibroblasts respond to} insulin stimulation-AKT phosphorylation at serine 473 occurs downstream of insulin binding to the insulin receptor and is considered one of the main markers for insulin signaling (Bae et al., 2003). Primary dermal foreskin fibroblasts demonstrated increased pAKT (Figure 3A) in response to insulin stimulation ( $<<0.001$ ); while no significant changes in total AKT (Figure 3B) were observed $(p>0.05)$.

\subsection{DISCUSSION}

We demonstrate that foreskin primary fibroblasts can be plated and grown from foreskin tissue collected following circumcision of human infants. These dermal primary foreskin fibroblasts can differentiate into adipocyte-like cells expressing increased and decreased mRNA levels of FABP4 and RIN3, respectively, as well as increased RIN3 DNA methylation. These cells also display increased phosphorylation of AKT when stimulated with insulin. Thus, this tissue appears to be a good surrogate for examining the influences of birth weight or environmental parameters during pregnancy on metabolic activity in offspring utilizing a tissue that comes directly from the neonate after birth.

We recognize that gene expression in the foreskin is not likely the driving factor for later life onset of obesity or diabetes; however, cells of foreskin are representative of the types of programming that can occur. Further, one study demonstrates that skin glucose content correlates to venous blood glucose levels in individuals with type 1 diabetes undergoing a three stage glucose clamp (Jensen et al., 1995); indicating that a relationship between skin glucose and whole body plasma glucose exists. Whether or not these findings would be demonstrated in non-diabetic individuals is not known. However, it is likely that skin glucose uptake is mediated through insulin receptor substrate 2 (IRS2), as previous studies indicate that dermal fibroblasts lacking IRS2 have reduced cellular glucose uptake (Sadagurski et al., 2005). Thus, it appears that mechanisms of glucose uptake are similar between skin and other tissues more classically believed to be involved with regulating whole body blood glucose control. While earlier studies by others were not directly performed in foreskin dermal tissue, we demonstrate that this tissue maintains the basic features of insulin signaling similar to other tissues. Therefore, experiments in foreskin tissue and foreskin dermal primary fibroblasts are a critical step along the way to examining how environmental exposures during pregnancy may impact offspring glucose regulation and will serve to guide upcoming studies in humans. Future steps in our lab will be to examine radiolabeled glucose uptake in whole tissue and primary fibroblasts grown in culture, and these experiments will provide a functional measure of glucose homeostasis following a wide variety of environmental exposures in utero.

Thus, we demonstrate the capabilities of using foreskin dermal primary fibroblasts to examine adipogenic potential of cells from human infants. These findings confirm what others have shown in adult dermal primary fibroblasts (Jaager and Neuman, 2011). Collectively, these data support the use of foreskin from infants as a metabolically active 
tissue to examine insulin signaling and adipogenesis. Obesity and diabetes are associated with a shortened lifespan (Kitahara et al., 2014; Leal et al., 2009). Thus, identifying mechanisms which are altered in early life may identify individuals who are at a greater risk of dying early and provide a targeted approach for therapeutic interventions to increase healthy aging.

Other laboratories are currently utilizing skin derived fibroblasts to study aging. The ability to respond to environmental and cellular stress plays a role in healthy aging. Salmon et al. (Salmon et al., 2005) demonstrate that dermal fibroblasts from a long lived mice strain have developed a resistance to cellular oxidative and non-oxidative stress which may be a mechanism of their increased lifespan. These results provide exciting support for the use of primary dermal foreskin fibroblasts in stress response experiments to examine the role of developmental programming and aging. While the foreskin tissue can only be collected at birth from neonates following circumcision, we can collect skin biopsy samples from adults later in life which would allow us to make multiple comparisons over time of how genes adapt and change following various in utero stimuli with aging.

In summary, the proposed studies introduce a novel approach to examine insulin signaling and adipogenesis in neonatal tissue. Using skin as a means to study mechanistic alterations in infants is the only viable neonatal tissue that can be easily collected following birth (circumcision) as well as the individual ages into adulthood (skin biopsy). The foreskin should be considered a tissue of interest for fetal programming studies in order to assess mechanisms of dysfunction in insulin signaling and adipocyte differentiation in response to various maternal exposures during pregnancy. Utilizing this model provides the foundation for future studies to predict pediatric and adulthood obesity, diabetes, and ultimately early death risk. Maternal factors which may impact early aging in offspring, such as maternal smoking, obesity, and exercise, can be examined via this model and will provide direct evidence of those factors which promote early aging in offspring. Thus, future studies should work towards long-term follow-up outcomes, examining the foreskin tissue shortly after birth and skin tissue into adulthood following specific maternal exposures to examine mechanisms of healthy (or diseased) aging, as well as the predictive potential of this tissue prospectively in children's growth and metabolic related outcomes.

\section{Acknowledgments}

We would like to thank the Maternal-Fetal Medicine Division at the University of Kentucky for access to fresh tissues. Funding was provided by the Graduate Center for Nutritional Sciences at the University of Kentucky (K.J.P.) and the National Institutes of Health (R01ES022223 to C.J.M). Leryn Reynolds was supported by an American Heart Association Post-Doctoral Fellowship (15POST25110002). Brett Dickens was supported by a CCTS Professional Student Mentored Research Fellowship.

\section{REFERENCE LIST}

Alfaradhi MZ, Fernandez-Twinn DS, Martin-Gronert MS, Musial B, Fowden A, Ozanne SE. Oxidative stress and altered lipid homeostasis in the programming of offspring fatty liver by maternal obesity. Am J Physiol Regul Integr Comp Physiol. 2014; 307:R26-R34. [PubMed: 24789994]

Bae SS, Cho H, Mu J, Birnbaum MJ. Isoform-specific regulation of insulin-dependent glucose uptake by Akt/protein kinase B. J Biol Chem. 2003; 278:49530-49536. [PubMed: 14522993] 
Barker DJ, Gluckman PD, Godfrey KM, Harding JE, Owens JA, Robinson JS. Fetal nutrition and cardiovascular disease in adult life. Lancet. 1993; 341:938-941. [PubMed: 8096277]

Carter LG, Lewis KN, Wilkerson DC, Tobia CM, Ngo Tenlep SY, Shridas P, Garcia-Cazarin ML, Wolff G, Andrade FH, Charnigo RJ, Esser KA, Egan JM, de Cabo R, Pearson KJ. Perinatal exercise improves glucose homeostasis in adult offspring. Am J Physiol Endocrinol Metab. 2012; 303:E1061-E1068. [PubMed: 22932781]

Carter LG, Qi NR, De Cabo R, Pearson KJ. Maternal exercise improves insulin sensitivity in mature rat offspring. Med Sci Sport Ex. 2013; 45:832-840.

CDC. National Center for Heath Statistics- Life Expectancy. Centers for Disease Control and Prevention; 2015.

Gavrilov LA, Gavrilova NS. Season of Birth and Human Longevity. J Anti Aging Med. 1999; 2:365366.

Gavrilov LA, Gavrilova NS. Early-life programming of aging and longevity: the idea of high initial damage load (the HIDL hypothesis). Ann N Y Acad Sci. 2004; 1019:496-501. [PubMed: 15247073]

Gavrilov LA, Gavrilova NS, Kroutko VN, Evdokushkina GN, Semyonova VG, Gavrilova AL, Lapshin EV, Evdokushkina NN, Kushnareva YE. Mutation load and human longevity. Mutat Res. 1997; 377:61-62. [PubMed: 9219579]

Green BB, Karagas MR, Punshon T, Jackson BP, Robbins DJ, Houseman EA, Marsit CJ. EpigenomeWide Assessment of DNA Methylation in the Placenta and Arsenic Exposure in the New Hampshire Birth Cohort Study (USA). Environ Health Perspect. 2016; 124:1253-1260. [PubMed: 26771251]

Harper JM, Salmon AB, Leiser SF, Galecki AT, Miller RA. Skin-derived fibroblasts from long-lived species are resistant to some, but not all, lethal stresses and to the mitochondrial inhibitor rotenone. Aging Cell. 2007; 6:1-13. [PubMed: 17156084]

Heijmans BT, Tobi EW, Stein AD, Putter H, Blauw GJ, Susser ES, Slagboom PE, Lumey LH. Persistent epigenetic differences associated with prenatal exposure to famine in humans. Proc Natl Acad Sci U S A. 2008; 105:17046-17049. [PubMed: 18955703]

Ino T. Maternal smoking during pregnancy and offspring obesity: meta-analysis. Pediatr Int. 2010; 52:94-99. [PubMed: 19400912]

Jaager K, Neuman T. Human dermal fibroblasts exhibit delayed adipogenic differentiation compared with mesenchymal stem cells. Stem Cells Dev. 2011; 20:1327-1336. [PubMed: 21142453]

Jensen BM, Bjerring P, Christiansen JS, Orskov H. Glucose content in human skin: relationship with blood glucose levels. Scand J Clin Lab Invest. 1995; 55:427-432. [PubMed: 8545601]

Kitahara CM, Flint AJ, Berrington de Gonzalez A, Bernstein L, Brotzman M, MacInnis RJ, Moore SC, Robien K, Rosenberg PS, Singh PN, Weiderpass E, Adami HO, Anton-Culver H, Ballard-Barbash R, Buring JE, Freedman DM, Fraser GE, Beane Freeman LE, Gapstur SM, Gaziano JM, Giles GG, Hakansson N, Hoppin JA, Hu FB, Koenig K, Linet MS, Park Y, Patel AV, Purdue MP, Schairer C, Sesso HD, Visvanathan K, White E, Wolk A, Zeleniuch-Jacquotte A, Hartge P. Association between class III obesity (BMI of $40-59 \mathrm{~kg} / \mathrm{m} 2$ ) and mortality: a pooled analysis of 20 prospective studies. PLoS Med. 2014; 11:e1001673. [PubMed: 25003901]

Krusinova E, Pelikanova T. Fatty acid binding proteins in adipose tissue: a promising link between metabolic syndrome and atherosclerosis? Diabetes Res Clin Pract. 2008; 82(Suppl 2):S127-S134. [PubMed: 18977052]

Leal J, Gray AM, Clarke PM. Development of life-expectancy tables for people with type 2 diabetes. Eur Heart J. 2009; 30:834-839. [PubMed: 19109355]

Miller RA, Chrisp C, Atchley W. Differential longevity in mouse stocks selected for early life growth trajectory. J Gerontol A Biol Sci Med Sci. 2000; 55:B455-B461. [PubMed: 10995043]

Miller RA, Harper JM, Galecki A, Burke DT. Big mice die young: early life body weight predicts longevity in genetically heterogeneous mice. Aging Cell. 2002; 1:22-29. [PubMed: 12882350]

Owings MSU, Williams Sonja. Trends in Circumcision for Male Newborns in U.S. Hospitals. 19792010. 2013

Ozanne SE, Hales CN. Lifespan: catch-up growth and obesity in male mice. Nature. 2004; 427:411412.

Exp Gerontol. Author manuscript; available in PMC 2018 August 01. 
Ozanne SE, Hales CN. Poor fetal growth followed by rapid postnatal catch-up growth leads to premature death. Mech Ageing Dev. 2005; 126:852-854. [PubMed: 15992609]

Padilla J, Jenkins NT, Thorne PK, Martin JS, Rector RS, Davis JW, Laughlin MH. Identification of genes whose expression is altered by obesity throughout the arterial tree. Physiol Genomics. 2014; 46:821-832. [PubMed: 25271210]

Rashid CS, Carter LG, Hennig B, Pearson KJ. Perinatal Polychlorinated Biphenyl 126 Exposure Alters Offspring Body Composition. J Pediatr Biochem. 2013; 3:47-53. [PubMed: 23741283]

Roseboom TJ, van der Meulen JH, Ravelli AC, Osmond C, Barker DJ, Bleker OP. Effects of prenatal exposure to the Dutch famine on adult disease in later life: an overview. Twin Res. 2001; 4:293298. [PubMed: 11869479]

Sadagurski M, Weingarten G, Rhodes CJ, White MF, Wertheimer E. Insulin receptor substrate 2 plays diverse cell-specific roles in the regulation of glucose transport. J Biol Chem. 2005; 280:1453614544. [PubMed: 15705592]

Salmon AB, Murakami S, Bartke A, Kopchick J, Yasumura K, Miller RA. Fibroblast cell lines from young adult mice of long-lived mutant strains are resistant to multiple forms of stress. Am J Physiol Endocrinol Metab. 2005; 289:E23-E29. [PubMed: 15701676]

Sun L, Sadighi Akha AA, Miller RA, Harper JM. Life-span extension in mice by preweaning food restriction and by methionine restriction in middle age. J Gerontol A Biol Sci Med Sci. 2009; 64:711-722. [PubMed: 19414512]

Swanson JM, Entringer S, Buss C, Wadhwa PD. Developmental origins of health and disease: environmental exposures. Semin Reprod Med. 2009; 27:391-402. [PubMed: 19711249]

Terra X, Quintero Y, Auguet T, Porras JA, Hernandez M, Sabench F, Aguilar C, Luna AM, Del Castillo $\mathrm{D}$, Richart C. FABP 4 is associated with inflammatory markers and metabolic syndrome in morbidly obese women. Eur J Endocrinol. 2011; 164:539-547. [PubMed: 21257725]

Wadhwa PD, Buss C, Entringer S, Swanson JM. Developmental origins of health and disease: brief history of the approach and current focus on epigenetic mechanisms. Semin Reprod Med. 2009; 27:358-368. [PubMed: 19711246]

Wang X, Zuckerman B, Pearson C, Kaufman G, Chen C, Wang G, Niu T, Wise PH, Bauchner H, Xu $\mathrm{X}$. Maternal cigarette smoking, metabolic gene polymorphism, and infant birth weight. JAMA. 2002; 287:195-202. [PubMed: 11779261]

Wens B, De Boever P, Verbeke M, Hollanders K, Schoeters G. Cultured human peripheral blood mononuclear cells alter their gene expression when challenged with endocrine-disrupting chemicals. Toxicology. 2013; 303:17-24. [PubMed: 23146750]

Zhang C, He Y, Okutsu M, Ong LC, Jin Y, Zheng L, Chow P, Yu S, Zhang M, Yan Z. Autophagy is involved in adipogenic differentiation by repressesing proteasome-dependent PPARgamma2 degradation. Am J Physiol Endocrinol Metab. 2013; 305:E530-E539. [PubMed: 23800883]

Zhang HY, Xue WY, Li YY, Ma Y, Zhu YS, Huo WQ, Xu B, Xia W, Xu SQ. Perinatal exposure to 4nonylphenol affects adipogenesis in first and second generation rats offspring. Toxicology Lett. 2014; 225:325-332.

Exp Gerontol. Author manuscript; available in PMC 2018 August 01. 


\section{Highlights}

- $\quad$ Foreskin primary fibroblasts accumulate lipid in response to an adipogenic cocktail

- Insulin stimulation increases insulin signaling in foreskin primary fibroblasts

- Foreskin is a useful tissue to study the developmental programming of aging 

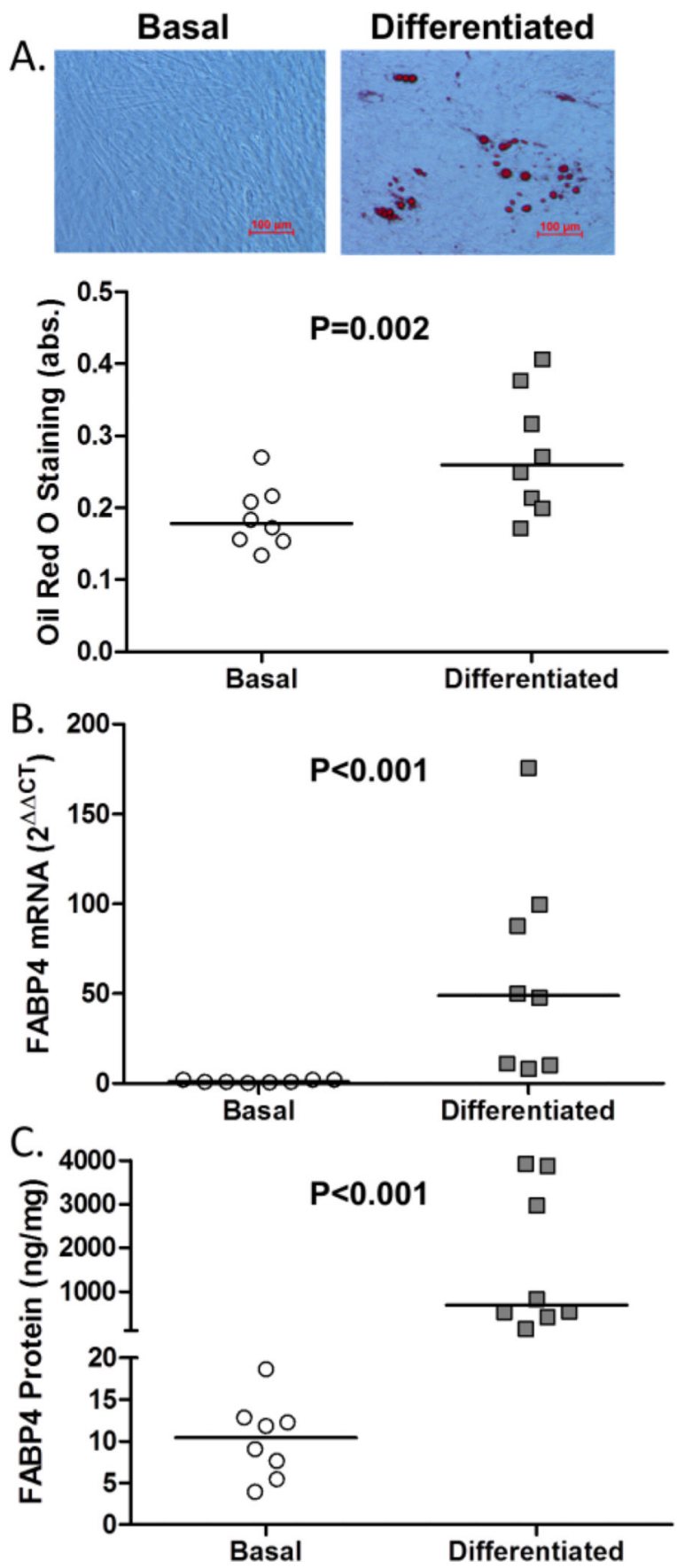

Figure 1.

Primary foreskin dermal fibroblasts following 14 days of basal media and adipocyte differentiation media. The cells were stained with Oil Red $\mathrm{O}$ in order to quantify lipid content $(A)$. Each image was obtained at a power of $20 \times$. Fatty Acid Binding Protein 4 $(\mathrm{FABP} 4)$ mRNA $(B)$ and protein $(C)$ increased following adipocyte differentiation. 
A.

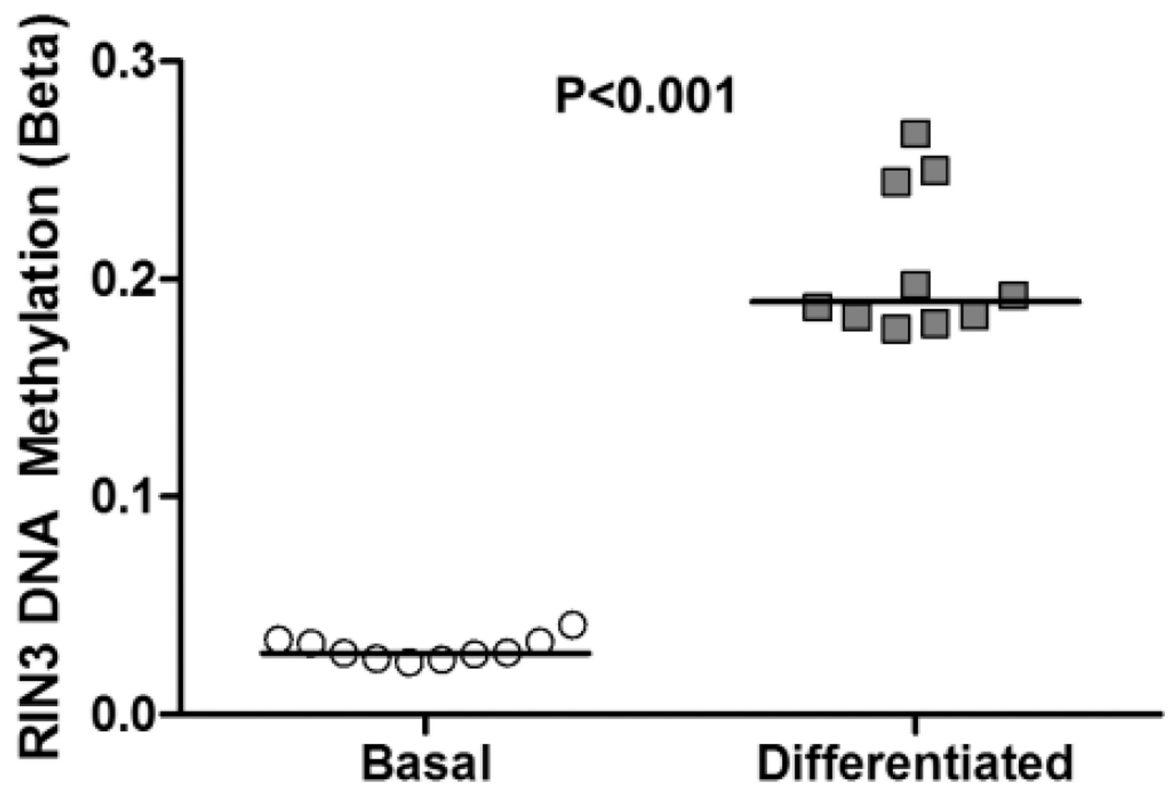

B.

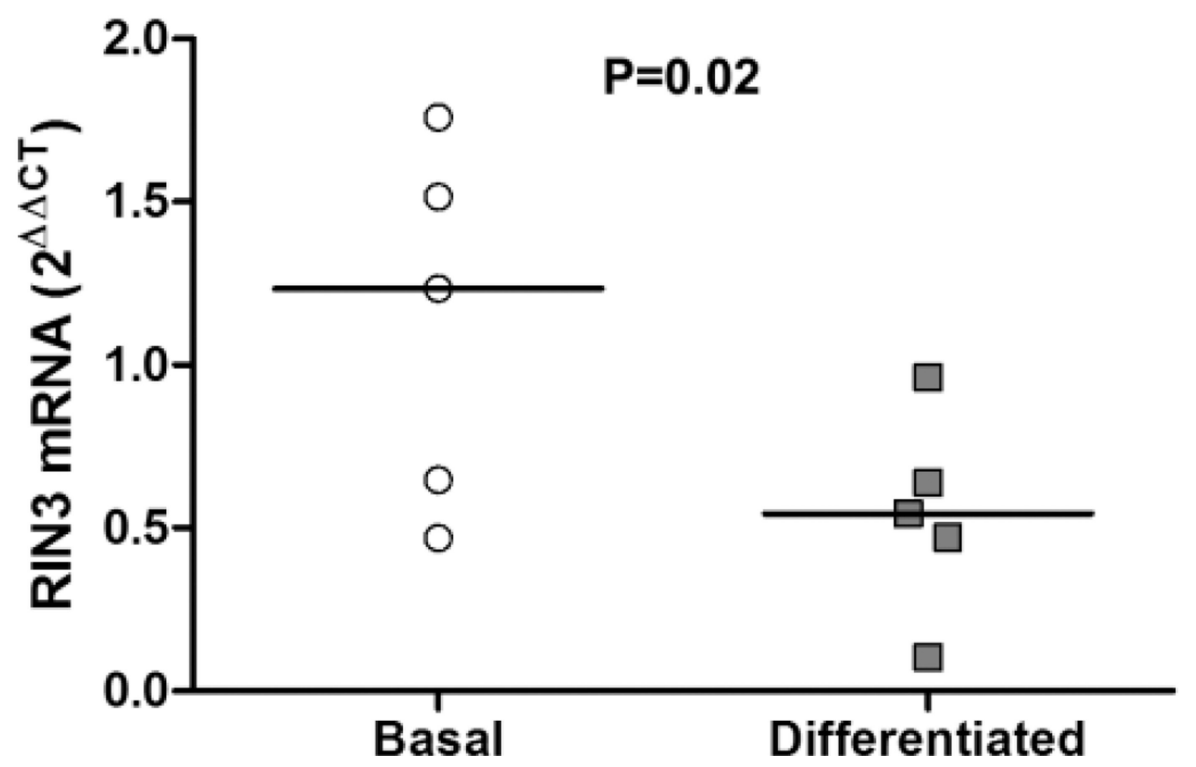

Figure 2.

Primary foreskin dermal fibroblasts DNA methylation at position 93077342 on chromosome 14 ( $A$ ) and mRNA expression $(B)$ of RIN3 48 hours after plating and following 14 days of adipocyte differentiation media. 
A.

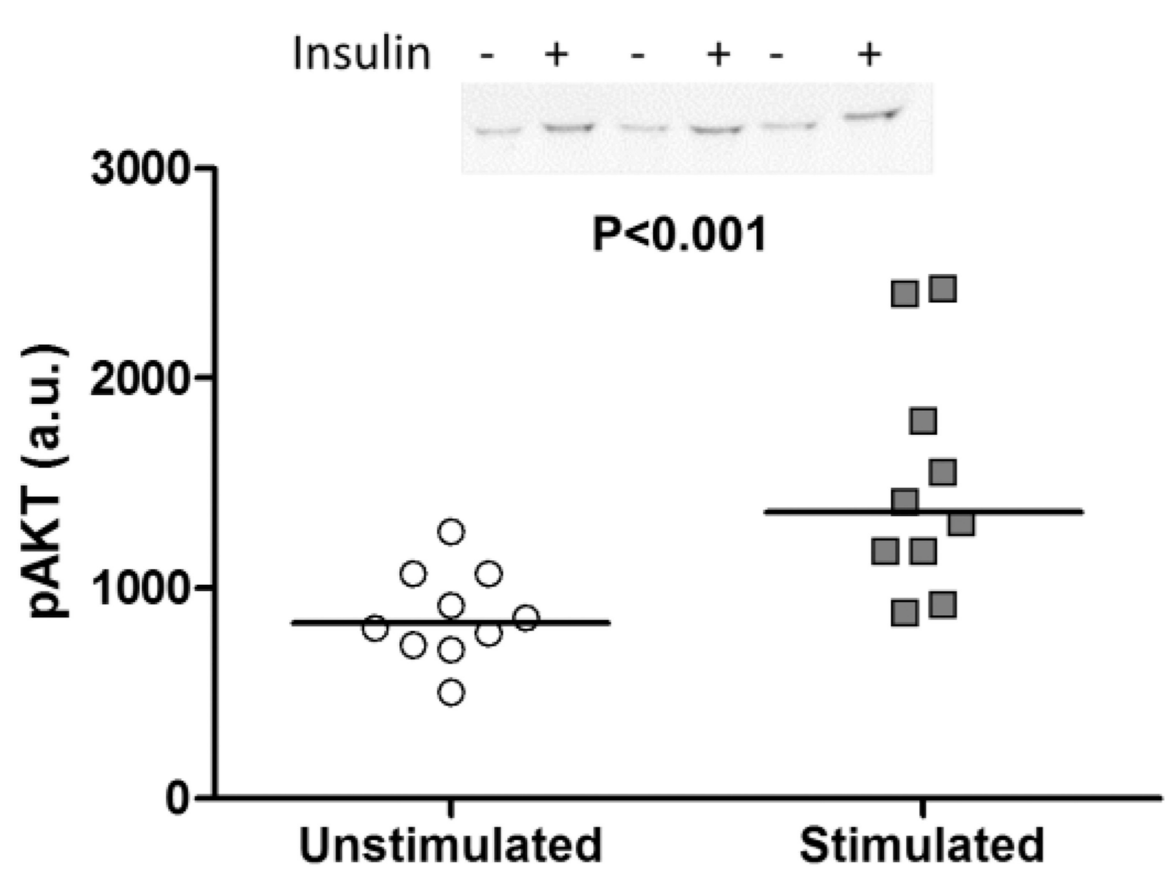

B.

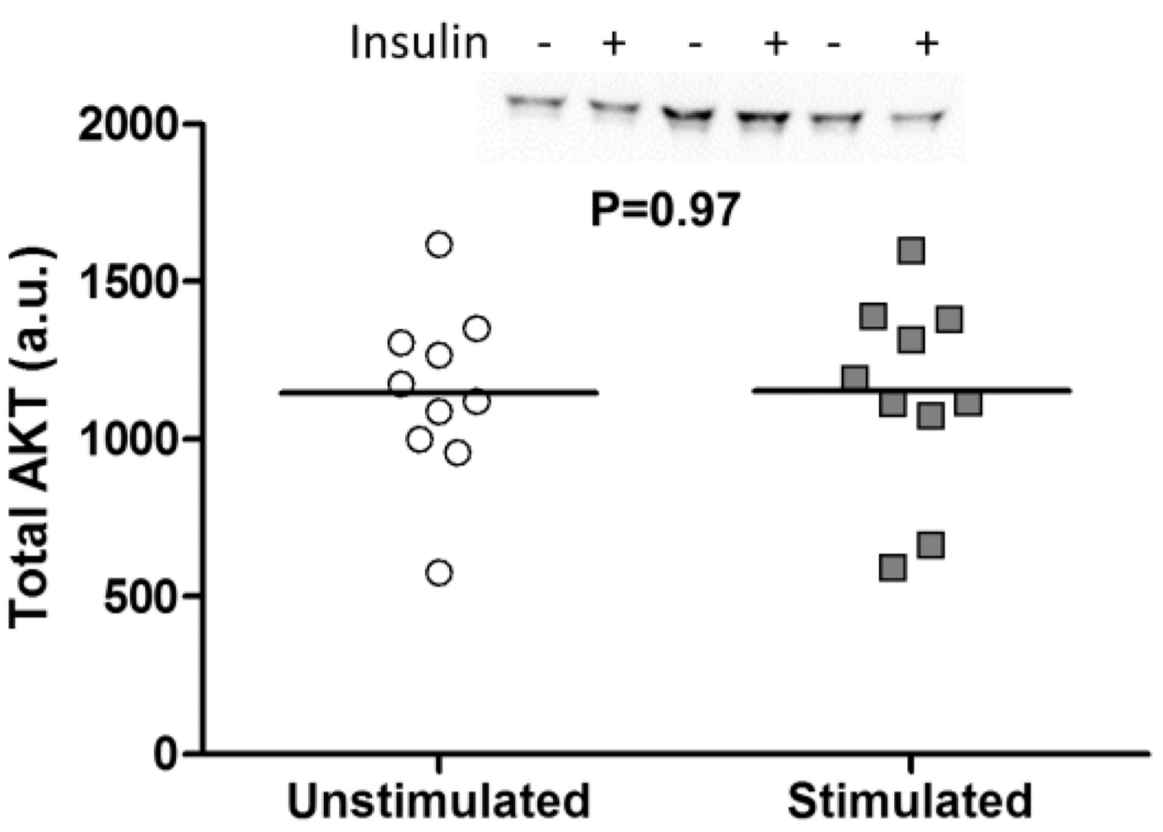

Figure 3.

Primary foreskin dermal fibroblasts with or without insulin had significantly increased AKT phosphorylation $(A)$ but showed no change in total AKT $(B)$. Three representative samples out of 10 different primary foreskin dermal fibroblasts are shown. 